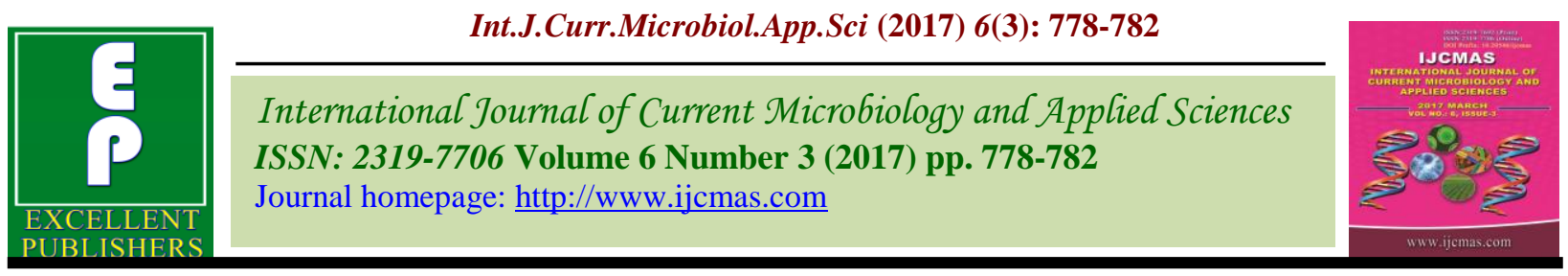

Original Research Article

https://doi.org/10.20546/ijcmas.2017.603.090

\title{
Impact of Different Transplanting Dates and Nutrient Sources on Soil Microbial Population and Grain Yield of Basmati Rice (Oryza sativa L.) grown under SRI
}

\author{
Arpita Sharma*, D. Kachroo, R. Puniya, Hardev Ram, Deepa Joshi, \\ Pooja Gupta Soni, Taramani Yadav and Malu Ram Yadav
}

\author{
Department of Agronomy, Sher-e-Kashmir University of Agricultural Sciences and Technology \\ of Jammu -180009, India \\ *Corresponding author
}

\section{A B S T R A C T}

\section{Keywords \\ Dates of transplanting, nutrient sources, basmati rice, SRI, total microbial count.}

\section{Article Info}

Accepted: 15 February 2017 Available Online: 10 March 2017

\begin{abstract}
A field experiment was carried out at the Research Farm, Division of Agronomy, Sher-eKashmir University of Agricultural Sciences and Technology, Jammu during the kharif season of 2014 to evaluate the effect of different transplanting dates and organic nutrient sources on growth and yield potential of basmati rice under system of rice intensification. The experiment consisted of three dates of transplanting and five nutrient sources. Results revealed that the transplanting of rice seedlings on June 30 produced significantly higher grain yield (33 q/ha) over July 15 (30 q/ha) and July 30 (28 q/ha) transplanting. The percent increase in grain yield with transplanting on June 30 and July 15 were in order of 18.59 and 9.71 over July 30, respectively. The application of $100 \%$ inorganic fertilizer i.e. recommended dose of fertilizer (RDF) recorded significantly higher grain yield (33 q/ha) which was statistically at par with vermicompost + FYM + neem oil cake and green manuring + vermicompost. The microbial population was found non-significant among the different date of transplanting. However, the significantly higher bacterial $4.20 *(10) \AA$ and fungal $4.12 *\left(10^{4}\right)$ À count was recorded with green manuring + Vermicompost. Whereas, significantly higher actinomycetes count $25.56 *\left(10^{4}\right)$ was observed in treatments applied with $100 \%$ Brown manuring than $100 \%$ inorganic and FYM + vermicompost + neem oil cake but it was statistically at par with green manuring + vermicompost and Brown manuring $+25 \%$ RDF. Based on one year experiment we concluded that transplanting of rice seedling at 30 June with green manuring + Vermicompost was recorded highest yield with sustain soil environment.
\end{abstract}

\section{Introduction}

Low productivity of rice in India is a major concern for food and nutritional security of more than $60 \%$ population which is dependent on rice. The increasing scarcity of water for agriculture is becoming a major problem in many countries, particularly the leading rice-producing countries like China and India, where competition for freshwater and growing demands for other sectors are increasing in future. In such a situation, the use of water-saving approaches, such as aerobic rice, direct-seeded rice and system of rice intensification (SRI) may prove beneficial while improving rice productivity 
as well. The SRI is an alternative for conventional rice cultivation that saves the expensive external inputs, improves soil health/quality and protects the environment substantially (Ram et al., 2014). In India fertilizer has become essential to modern agriculture to feed the growing population. Use of fertilizers, especially, the chemical fertilizers has brought in blessings on humanity, which helped to overcome hunger in different corners of the world. Though chemical fertilizers increase crop production but their overuse has resulted in hardening of the soil, adversely affected its health and fertility and replenishment potential. Soil is the habitat of a diverse array of organisms which include both micro flora and fauna, and this soil biodiversity help it to maintain its health and make it resilient to pressure due to intensive cropping. Soil micro organisms play a very important role in soil fertility not only because of their ability to carry out biochemical transformation but also due to their importance as a source and sink of mineral nutrients (Jenkinson and Ladd, 1981). The soil microbial community is involved in numerous ecosystem functions, such as nutrient cycling and organic matter decomposition, and plays a crucial role in the terrestrial carbon cycle (Schimel, 1995). The microbial communities possesses potential for rapid growth and turnover, means the microbial community is a more reactive component of a terrestrial ecosystem to external stress than plants and animals (Panikov, 1999). Changes in microbial communities can be use to predict the effects of ecosystem perturbations by organic and conventional management practices (Poudel et al., 2002). Application of organic fertilizers is one of important practical measures to improve soil fertility. In addition to providing necessary nutrients for crops and improving soil physico-chemical properties, organic fertilizer is able to enhance soil microbial activity of soil, such as improving activity of soil enzymes and increasing soil microbial biomass (Lv et al., 2005). Keeping foresaid points in mind, an experiment with different dates of transplanting under organic nutrient sources in SRI was carried out to assess its impact on soil beneficial microbial biomass.

\section{Materials and Methods}

A field experiment was conducted at the research farm of Division of Agronomy of Sher-e-Kashmir University of Agricultural Sciences and Technology of Jammu during the year 2014. The soil of the experimental site was sandy clay loam, slightly alkaline in reaction, low in organic carbon $(0.35 \%)$ and available nitrogen $(231.73 \mathrm{~kg} / \mathrm{ha})$, but medium in available phosphorus (13.86 $\mathrm{kg} / \mathrm{ha})$ and potassium (156.93 kg/ha). The experiment was laid under Randomized block design which consisted of three dates of transplanting (June $30^{\text {th }}$; July $15^{\text {th }}$ and July $\left.30^{\text {th }}\right)$ and five nutrient sources $(100 \%$ inorganic fertilizer (RDF); Brown manuring with Sesbania $+25 \%$ inorganic fertilizer (RDF); Brown manuring with Sesbania $(100 \%) ; \mathrm{FYM}+$ Vermicompost + Neem oil cake (1:1:1) and Green manuring with Sesbania + Vermicompost (1:1). The rice variety basmati-370 was used as test material. Green manure crop was raised and incorporated in soil at 30 days crop stage after sowing during puddling. The FYM, Vermicompost and neem oil cake were applied 20 days before transplanting, where as Sesbania in brown manuring treatments was sown one day after transplanting of Basmati rice (sprayed with 2-4, D at 30 days crop stage). Basal applications of inorganic fertilizer at time of transplanting were applied @ 30-20-10 kg N-P-K/ha. Nitrogen was applied in three splits $(1 / 2$ as basal and remaining $1 / 4$ in two equal splits at maximum tillering and panicle initiation stage) as per the treatment. Transplanting of 12 days old seedling was done at spacing of $25 \times 25 \mathrm{~cm}$ 
apart. Enumeration of fungi, bacteria and actinomycetes was done by the serial dilution -agar plating method or viable plate count method. The initial microbial composition of soil bacteria was $3.01 *\left(10^{5}\right)$, actinomycetes$17.91 *\left(10^{4}\right)$ and fungi-2.34*(10 $)$.

\section{Procedure for serial dilution - agar plating method or viable plate count method}

A known amount (10 $\mathrm{ml}$ or $10 \mathrm{~g})$ of material is suspended or agitated in known volume of sterile water blank $(90 \mathrm{ml}$ or so to make the volume to $100 \mathrm{ml}$ ) to make a microbial suspension. Serial dilutions $10^{-2}, 10^{-3}, \ldots 10^{-7}$ are made by pipetting measured volumes (usually $1 \mathrm{ml}$ or $10 \mathrm{ml}$ ) into additional dilution blanks (having $99 \mathrm{ml}$ or $90 \mathrm{ml}$ sterile water). Finally $1 \mathrm{ml}$ aliquat of various dilutions are added to sterile petridishes (triplicate for each dilution) to which are added $15 \mathrm{ml}$ (approx.) of sterile, cool, molten $\left(45^{\circ} \mathrm{C}\right)$ media (Nutrient agar for bacteria, Glycerol yeast agar for actinomycetes and Sabouraud agar medium, supplemented with streptopenillin, $10 \mu \mathrm{g} / \mathrm{ml}$, for fungi). The dilutions $10^{-2}$ to $10^{-5}$ are selected for enumeration of fungi, $10^{-3}$ to $10^{-6}$ for actinomycetes and $10^{-4}$ to $10^{-7}$ for bacteria relative to their proportion in soil . On the solidification, plates are incubated, in an inverted position for 3-7 days at $25^{\circ} \mathrm{C}$. The number of colonies appearing on dilution plates are counted, averaged and multiplied by the dilution factor to find the number of cells/spores per gram (or millimeter) of the sample:

No. of colonies (average of 3 replications) $\times$ Dilution factor

No. of cells $/ \mathrm{ml}$ or $\mathrm{g}=$

Dry wt. of soil

Dilution factor $=$ Reciprocal of the dilution (e.g. $10^{-7}=10^{7}$ )

\section{Results and Discussion}

\section{Grain yield}

The mean data on grain yield revealed that the basmati rice (B-370) transplanted on June 30 produced significantly higher grain yield (32.72 q/ha) than July 15 (30.27 q/ha) and July $30(28 \mathrm{q} / \mathrm{ha})$. Higher yields at earlier transplanting might be due to better vegetative phase that favored uptake of nutrients (Table 1) and there by increased grain yield. Paddy yields reduced with delayed transplanting by the way of large negative growth and lower photosynthetic rate resulting in ineffective tillers (Ding and Chai, 1982). The application of inorganic nutrient sources (100\% RDF) significantly increase the grain yield $(32.83 \mathrm{q} / \mathrm{ha})$ of basmati as compared to organic nutrient sources. Among the organic sources FYM + vermicompost + neem oil cake $(1: 1: 1)$ being at par with green manuring + vermicompost $(1: 1)$ and brown manuring $+25 \%$ RDF produced higher grain yield of basmati rice over application of organic nutrients through brown manuring $(100 \%)$. This may owe to greater release of nutrients and their ready availability in soil in case of recommended (inorganic) dose which facilitated higher uptake and hence contributing towards higher yield (Jana and Ghosh, 1996).

\section{Total microbial count}

The data on total microbial count at harvest revealed that different date of transplanting failed to produce any significant results but in case of different nutrient sources, they significantly affected the microbial counts (Table 1). Among the different nutrient 
sources bacterial and fungal count was significantly higher with green manuring + vermicompost followed by $100 \%$ Brown manuring. Whereas, significantly higher actinomycetes count was observed in treatments supplied with $100 \%$ Brown manuring as compared to $100 \%$ inorganic and FYM + vermicompost + neem oil cake but it was statistically at par with green manuring + vermicompost and brown manuring $+25 \%$ RDF.

Table.1 Influence of Transplanting dates and nutrient sources on total microbial count (CFU/g soil) at harvest

\begin{tabular}{lcccc}
\hline \multicolumn{1}{c}{ Treatment } & $\begin{array}{c}\text { Grain yield } \\
(\mathbf{q} / \mathbf{h a})\end{array}$ & Bacteria $\mathbf{( \mathbf { 1 0 } ^ { 5 } )}$ & $\begin{array}{c}\text { Actinomycetes } \\
\left(\mathbf{( 1 0}^{\mathbf{4}}\right)\end{array}$ & $\begin{array}{c}\text { Fungi } \\
(\mathbf{1 0}\end{array}$ \\
\hline Transplanting dates & & & & \\
\hline June 30 & 32.72 & 3.73 & 22.37 & 3.51 \\
July 15 & 30.27 & 3.71 & 22.30 & 3.54 \\
July 30 & 27.59 & 3.72 & 22.63 & 3.48 \\
SEm \pm & 0.69 & 0.06 & 1.30 & 0.09 \\
LSD (p $\leq$ 0.05) & 2.00 & $\mathrm{NS}$ & $\mathrm{NS}$ & $\mathrm{NS}$ \\
\hline Nutrient Sources & & & & \\
\hline 100\% inorganic & 32.83 & 3.42 & 20.56 & 2.57 \\
Brown manuring + 25\% & 28.79 & 3.89 & 22.44 & 3.39 \\
RDF & & & & 3.88 \\
Brown manuring 100\% & 26.01 & 3.95 & 25.56 & 3.59 \\
FYM + Vermicompost + & 30.21 & 3.15 & 18.28 & 4.12 \\
neem oil cake & & & & \\
Green manuring + & 29.80 & 4.20 & 25.33 & 0.11 \\
Vermicompost & & & & 0.33 \\
SEm \pm & 0.89 & 0.08 & 1.68 & \\
LSD (p $\leq 0.05)$ & 2.59 & 0.23 & 4.87 & \\
\hline
\end{tabular}

Soil microbial population (Actinomycetes, Bacteria and Fungi) increased with the application of nutrients with organic sources over inorganic sources i.e. chemical fertilizers except the organic source treatment where neem oil cake was applied along with FYM + vermicompost in equal proportions. The lowest CFU of bacterial and actinomycetes was observed in treatments supplied with FYM + vermicompost + neem oil cake, which could be attributed to antagonistic effect of neem oil cake. These changes in composition of microbial communities might be due to presence higher organic matter which improved the beneficial micro organism population. These results were in conformity 
with that of Jha et al., (2004) and Asari et al., (2008). Based on one year experiment we concluded that transplanting of rice seedling at 30 June with green manuring + Vermicompost recorded highest grain yield of basmati rice with sustain soil environment in the identical agro-ecological condition of Jammu.

\section{References}

Asari, N., Ishihara, R., Nakajima, Y., M. and Asakawa, S. 2008. Cynobacterial communities of rice straw left on the soil surface of a paddy field. Biol. Fertility of Soils, 44: 605-612.

Ding, C.L. and Chai, Y.Z. 1982. A Study on the critical period of transplanting for the second crop. Shanghai Agri. Sci. Technol., 4: 4-7.

Jana, M.K. and Ghosh, B.C. 1996. Integrated nutrient management in rice (Oryza sativa L.)-rice crop sequence. Indian $J$. Agronomy, 41(2): 183-187.

Jenkinson, D.S. and Ladd, J.N. 1981. Microbial Biomass in Soil: Measurement and Turnover. In: Soil Biochemistry, Paul, E.A. and J.N. Ladd (Eds.). Marcel Dekker, New York, USA., pp: 415-471.

Jha, M.N., Prasad, A.N. and Misra, S.A. 2004. Influence of source of organics and soil organic matter content on cynobacterial nitrogen fraction and distributional pattern under different water regimes: World J. Microbiol. Biotechnol., 20: 673-677.

Lv, W.G., Huang, Q.W., Shen, Q.R. 2005. The effect of organic fertilizer and organic-inorganic fertilizer application on soil enzymes activities during watermelon growing period. J. Nanjing Agri. Univ., 28: 67-71.

Panikov, N.S. 1999. Understanding and prediction of soil microbial community dynamics under global change. Appl. Soil Ecol., 11: 161-176.

Poudel, D.D., Horwarth, W.R., Lanini, W.T., Temple, S.R. and Van-Bruggen, A.H.C. 2002. Comparison of soil $\mathrm{N}$ availability and leaching potential, crop yields and weeds in organic, low-input and conventional farming systems in northern California. Agric. Ecosyst. Environ., 90: 125-137.

Ram, H., Singh, J.P., Bohra, J.S., Singh, R.K. and Sutaliya, J.M. 2014. Effect of seedlings age and plant spacing on growth, yield, nutrient uptake and economics of rice (Oryza sativa) genotypes under system of rice intensification. Indian J. Agronomy, 59(2): 256-260.

Schimel, D.S. 1995. Terrestrial ecosystem and carbon cycle. Global Change Biol., 1: 77- 91.

\section{How to cite this article:}

Arpita Sharma, D. Kachroo, R. Puniya, Hardev Ram, Deepa Joshi, Pooja Gupta Soni, Taramani Yadav and Malu Ram Yadav. 2017. Impact of Different Transplanting Dates and Nutrient Sources on Soil Microbial Population and Grain Yield of Basmati Rice (Oryza sativa L.) grown under SRI. Int.J.Curr.Microbiol.App.Sci. 6(3): 778-782.

doi: https://doi.org/10.20546/ijcmas.2017.603.090 